\title{
Pengukuran Panjang dan Lebar Pori Stomata Daun Beberapa Varietas Tanaman Kacang Tanah (Arachis hypogaea L.)
}

\author{
Hesty Ester Talutaa, Henny L. Rampea*, Marhaenus J. Rumondora* \\ aJurusan Biologi, FMIPA, Unsrat, Manado
}

KATA KUNCI

Panjang stomata, Lebar stomata, Pori Stomata, Kacang Tanah (Arachis hypogaea L.) varietas Lokal Gajah, Kelinci dan Jerapah.

\begin{abstract}
A B S T R A K
Kacang tanah (Arachis hypogaea L.) merupakan salah satu tanaman pangan bernilai ekonomi tinggi, dan sebagai tanaman kacang-kacangan terpenting kedua setelah kedelai.Pori stomata merupakan tempat terjadinya pertukaran gas dan air antara atmosfer dengan sistem ruang antar sel yang berada pada jaringan mesofil di bawah epidermis.Setiap varietas tanaman kacang tanah memiliki respon terhadap faktor lingkungan yang berbeda seperti ketahanan terhadap cekaman fisilogis termasuk kemampuan membuka dan menutupnya stomata.Penelitian ini bertujuan untuk mengukur panjang dan lebar pori stomata daun beberapa varietas kacang tanah (Arachis hypogaeaL.). Penelitian dilaksanakan di rumah plastikFakultas MIPA Unsrat selama 30 hari. Hasil penelitian menunjukkan bahwa keempat varietas memiliki panjang dan lebar stomata yang lebih panjang adalah varietas Gajah 81,80 $\pm 28,72 \mu \mathrm{m}$, varietas Lokal 79,81 $\pm 24,85 \mu \mathrm{m}$, varietas Jerapah 69,28 $\pm 22,60 \mu \mathrm{m}$ dan varietas Kelinci $57,22 \pm 25,02 \mu \mathrm{m}$. Lebar pori stomata yang membuka lebih besar adalah varietas Lokal 31,13 \pm 9,77 $\mu \mathrm{m}$, varietas Gajah 29,22 $\pm 3,71 \mu \mathrm{m}$, varietas Jerapah 27,72 $\pm 11,65 \mu \mathrm{m}$ dan varietas Kelinci 21,32 $\pm 12,78 \mu \mathrm{m}$.

\section{A B S T R A C T}

Peanut are one of the high value food plants and as the second highest bean crop after soybeans. The Pore of Stomata plays was a place of gas and water exchange between the atmosphere and the intercellular space located in the mesophyll tissue beneath the epidermis. Each variety of peanut crops has responses to different environmental factors such as resistance to physical stress, including the ability to open and close the stomata. This study aims to measure the length and width of stomata pores of several peanut varieties (Arachis hypogaea L.). The research was conducted in plastic house of Faculty of Mathematics and Natural Sciences Unsrat for 30 days. The results showed that the four varieties had length and stomatal length $81,80 \pm 28,72 \mu \mathrm{m}$, followed by local varieties $79,81 \pm 24,85 \mu \mathrm{m}$, giraffe varieties $69,28 \pm 22,60$ $\mu \mathrm{m}$ and 57,22 \pm rabbit varieties $25.02 \mu \mathrm{m}$. Stomatal pore $31.13 \pm 9.77 \mu \mathrm{m}$, followed by elephant varieties $29.22 \pm 3.71 \mu \mathrm{m}$, giraffe varieties $27.72 \pm$ $11.65 \mu \mathrm{m}$ and rabbit varieties $21.32 \pm 12.78 \mu \mathrm{m}$.
\end{abstract}

\begin{tabular}{l}
\hline TERSEDIA ONLINE \\
\hline 1 Agustus 2017 \\
\hline
\end{tabular}

1. Pendahuluan

Kacang tanah (Arachis hypogaea L.) merupakan salah satu tanaman pangan bernilai ekonomi tinggi, dan sebagai tanaman kacang-kacangan terpenting kedua setelah kedelai. Pemanfaatan tanaman kacang tanah sangat beragam, antara lain sebagai bahan sayur, saus, digoreng atau direbus. Sebagai bahan industri, kacang tanah dapat dibuat keju, mentega, sabun dan minyak. Daun kacang tanah dapat digunakan sebagai pakan ternak dan pupuk hijau (Suprapto, 2000).Stomata merupakan celah atau lubang-lubang kecil yang dikelilingi oleh dua sel epidermis khusus yang disebut sel penutup dan

*Corresponding author: Jurusan Biologi FMIPA UNSRAT, Jl. Kampus Unsrat, Manado, Indonesia 95115; Email address: htaluta@yahoo.com Published by FMIPA UNSRAT (2017) 
terdapat pada permukaan daun, stomata disebut juga dengan mulut daun. Stomata berfungsi sebagai alat pernapasan bagi tumbuhan dan sebagai jalan masuknya $\mathrm{CO}_{2}$ dari udara pada proses fotosintesis serta sebagai jalan untuk proses penguapan (transpirasi) (Lidahshiro, 2009). Pori stomata merupakan tempat terjadinya pertukaran gas dan air antara atmosfer dengan sistem ruang antar sel yang berada pada jaringan mesofil di bawah epidermis (Mulyani, 2006). Stomata dapat ditemukan pada bagian permukaan tanaman misalnya daun dan batang, tetapi yang lebih banyak terdapat pada daun. Sebagian besar tumbuhan Magnoliophyta memiliki stomata di permukaan bawah daun disebut hipostomatus. Sedangkan tumbuhan akuatik yang mengapung, stomata hanya terdapat pada permukaan atas daun, dan pada tanaman lainnya stomata terdapat pada kedua permukaan daun (Wilkins, 1991).

Produksi kacang tanah tergantung dari efisiensi tumbuhan mengubah $\mathrm{CO}_{2}$ menjadi senyawa karbohidrat dalam proses fotosintesis. Selanjutnya besarnya difusi $\mathrm{CO}_{2}$ pada tumbuhan tergantung pada pembukaan pori stomata. Membuka dan menutupnya stomata tergantung dari turgor sel penutup, ketersediaan air dalam sel tumbuhan yang cukup memungkinkan stomata membuka secara optimal.

Data Balai Penelitian Aneka Tanaman Kacang dan Umbi (BALITKABI) kota Malang di Indonesia telah dilepas varietas unggul kacang tanah, dimana setiap varietas memiliki sifat khas sendiri dalam hal sifat biologi tumbuhan, komposisi kimia biji, resistensi terhadap penyakit karat dan bercak daun dan toleransi abiotik (Suhartina, 2005). Setiap varietas memiliki respon terhadap faktor lingkungan yang berbeda seperti ketahanan terhadap cekaman fisilogis termasuk kemampuan membuka dan menutupnya stomata.

Transpirasi merupakan proses hilangnya air dalam bentuk uap air dari tubuh tumbuhan yang sebagian besar terjadi melalui stomata, selain itu air juga dapat keluar melalui kutikula dan lentisel (Dardjat dan Siregar, 1996). Apabila laju transpirasi terlalu cepat dapat merugikan tumbuhan yang menyebabkan jaringan kehilangan air terlalu banyak selama musim panas dan kering (Lovelles, 1991).

Berdasarkan hal tersebut maka dilakukan penelitian pengukuran panjang dan lebar pori stomata daun beberapa varietas kacang tanah (Arachis hypogaea L.).

\section{Material dan Metode}

Penelitian ini dilaksanakan selama 3 bulan, dimulai dari bulan Februari-April 2017 di Rumah Plastik dan Laboratorium Dasar Biologi Fakultas MIPA Universitas Sam Ratulangi Manado.

\section{Alat dan Bahan}

Alat-alat yang digunakan untuk penelitian ini adalah Mikroskop Olympus binokuler tipe CX-22, optilab advance tipe 2.2 dan program Image Raster tipe 3.0, laptop, kaca benda, kaca penutup, cat kuku, silet, gunting dan cool box. Bahan yang digunakan dalam penelitian ini adalah benih tanaman kacang tanah varietas Gajah, Kelinci, Jerapah yang diperoleh dari Balai Penelitian Aneka Tanaman Kacang dan Umbi (BALITKABI) Kota Malang, sedangkan varietas lokal diperoleh dari petani di kota Tomohon, air, tanah, pupuk TSP, polibag dan kertas label.

Prosedur penelitian meliputi:

Persiapan Media Tanam

Tanah yang akan digunakan dikeringanginkan, dibersihkan dari sisa-sisa akar dan gulma. Selanjutnya tanah diayak dan dimasukkan ke dalam polibag berukuran $25 \times 30 \mathrm{~cm}$ sebanyak 3 $\mathrm{kg} /$ polibag.

Penanaman Benih dan Pemeliharaan

Benih kacang tanah direndam dalam air selama 2 jam, selanjutnya setiap polibag ditanami 2 benih kacang tanah. Pemeliharaan meliputi penyiraman tanaman dilakukan setiap hari sebanyak $250 \mathrm{ml}$ air, dan penyiangan dilakukan apabila terdapat gulma yang tumbuh di dalam polibag. Pengamatan dilakukan setelah tanaman mencapai pertumbuhan vegetatif maksimal yaitu 30 hari setelah tanam.

Pembuatan Preparat, Pengukuran Panjang dan Lebar Stomata

Pengambilan sampel daun tanaman kacang tanah dilakukan pada pukul 08.05-09.05 WITA. Daun kacang tanah yang dijadikan sampel penelitian yaitu daun yang telah mencapai pertumbuhan maksimal, berwarna hijau tua yaitu daun keempat dari pucuk tanaman. Permukaan epidermis bawah daun diolesi cat kuku, dibiarkan kering selama 5-10 menit. Kegunaan pemberian cat kuku adalah untuk mempertahankan stomata tetap terbuka. Daun kacang tanah dipetik dan dimasukkan dalam cool box dan dibawa ke laboratorium untuk dibuat preparat segar.

Prosedur pembuatan preparat segar daun tanaman kacang tanah menurut Sumargono (1992) yang dimodifikasi sebagai berikut :

1. Dibuat irisan memanjang epidermis daun bagian bawah kacang tanah

2. Hasil irisan epidermis diletakkan di atas gelas benda, kemudian ditutup dengan gelas penutup

3. Agar tidak lepas sudut-sudut gelas penutup ditetesi cat kuku dan diberi label, selanjutnya mikroskop dihubungkan dengan optilab

4. Bila hasil pengamatan stomata telah mendapatkan hasil yang baik, dilakukan pengambilan gambar (Image Capture) dengan menggunakan optilab yang hasilnya langsung dilihat pada monitor laptop. Pengukuran panjang dan lebar 
pori stomata menggunakan program Image Raster tipe 3.0.

3. Hasil dan Pembahasan

Struktur anatomi stomata daun kacang tanah (Arachis hypogaeaL.)

Data hasil irisan memanjang epidermis bawah daun kacang tanah dari setiap varietas ditunjukan pada Gambar 5.

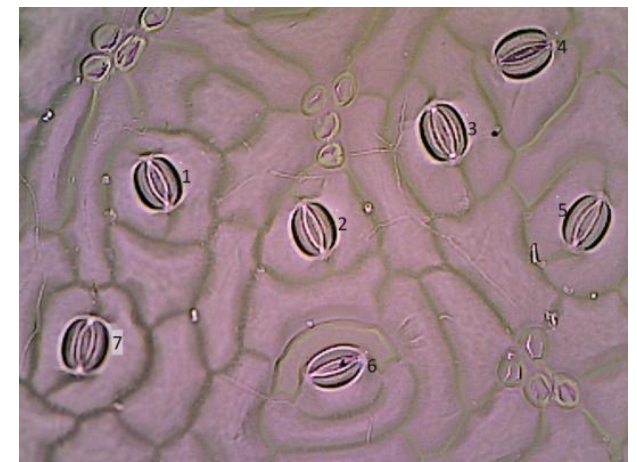

Gambar 5. Anatomi stomata daun tanaman kacang tanah.

Berdasarkan gambar diatas terlihat bahwa tipe stomata dari tanaman kacang tanah berbentuk ginjal (tipe heleborus), dengan dinding punggung dan perut tipis, sedangkan dinding bagian atas dan bawah lebih tebal. Panjang sel penutup serta celah stomata daun tanaman kacang tanah dikelilingi oleh dua buah sel tetangga yang letaknya tegak lurus dan disebut tipe parasitik.

Stomata pada umumnya diapit oleh sepasang sel penjaga. Sel penjaga tersebut mengontrol diameter stomata dengan cara mengubah bentuk dan akan menyempitkan atau melebarkan celah diantara kedua sel tersebut (Campbell, 2003).

Membuka dan menutupnya stomata dapat dipengaruhi oleh beberapa faktor diantaranya yaitu cahaya, konsentrasi $\mathrm{CO}_{2}$, suhu, kelembaban dan hormon tumbuhan. Cahaya sinar matahari menyebabkan membukanya stomata pada siang hari, dalam hal ini tumbuhan menangkap cahaya menggunakan pigmen yang disebut dengan klorofil. Sedangkan dalam keadaan gelap atau tidak ada cahaya matahari terjadi peningkatan konsentrasi $\mathrm{CO}_{2}$ dan turunnya kelembaban menyebabkan menutupnya stomata (Kearn dan Assmann, 1993, Hopkins, 2004).

\section{Panjang pori stomata daun kacang tanah (Arachis hypogaea L.)}

Data pengukuran panjang pori stomata saat terbuka dapat dilihat pada Gambar 6. Hasil pengukuran rata-rata panjang pori stomata setiap ulangan dari empat varietas kacang tanah ditunjukan pada Tabel 1.

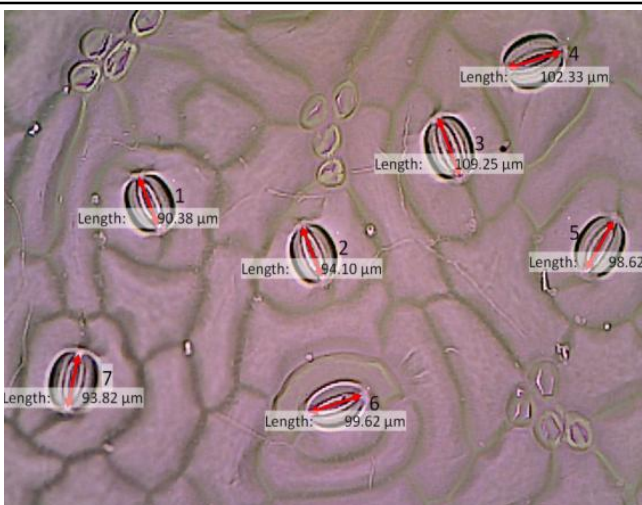

Gambar 6. Pengukuran panjang pori stomata daun kacang tanah

Tabel 1. Rata-rata panjang pori stomata daun beberapa varietas tanaman kacang tanah dengan perbesaran (400X)

\begin{tabular}{|r|c|r|}
\hline No & $\begin{array}{c}\text { Varietas } \\
\text { kacang tanah }\end{array}$ & $\begin{array}{c}\text { Rata-rata } \\
\text { panjang pori } \\
\text { stomata }(\mu \mathrm{m}) \pm \mathrm{SD}\end{array}$ \\
\hline 1 & Lokal & $79,81 \pm 24,85$ \\
\hline 2 & Gajah & $81,80 \pm 28,72$ \\
\hline 3 & Kelinci & $57,22 \pm 25,02$ \\
\hline 4 & Jerapah & $69,28 \pm 22,60$ \\
\hline
\end{tabular}

Keterangan: $\pm \mathrm{SD}=$ Standar Deviasi

Berdasarkan Tabel diatas bahwa data rata-rata panjang stomata tertinggi dari setiap varietas yaitu varietas gajah $81,80 \pm 28,72 \mu \mathrm{m}$, diikuti dengan varietas lokal 79,81 $\pm 24,85 \mu \mathrm{m}$, varietas jerapah $69,28 \pm 22,60 \mu \mathrm{m}$ dan varietas kelinci 57,22 \pm 25,02 $\mu \mathrm{m}$.

Berdasarkan data Tabel 1 hasil rata-rata panjang pori stomata dari ke-4 varietas tanaman kacang tanah tertinggi yaitu pada kacang tanah varietas gajah dengan panjang pori stomata 81,80 $\mu \mathrm{m}$. Sehingga dalam penyerapan $\mathrm{CO}_{2}$, pori stomata akan menyerap $\mathrm{CO}_{2}$ lebih banyak karena panjang pori stomata berhubungan dengan lebar pori stomata, yaitu apabila stomata terbuka sel penutup hanya melebar dan panjang stomata dalam keadaan tetap saat stomata membuka.

\section{Lebar Pori Stomata Daun Kacang Tanah (Arachis hypogaea L.)}

Data pengukuran lebar pori stomata saat terbuka dapat dilihat pada Gambar 7. Hasil pengukuran lebar pori stomata setiap ulangan dari empat varietas kacang tanah ditunjukan pada Tabel 2. 


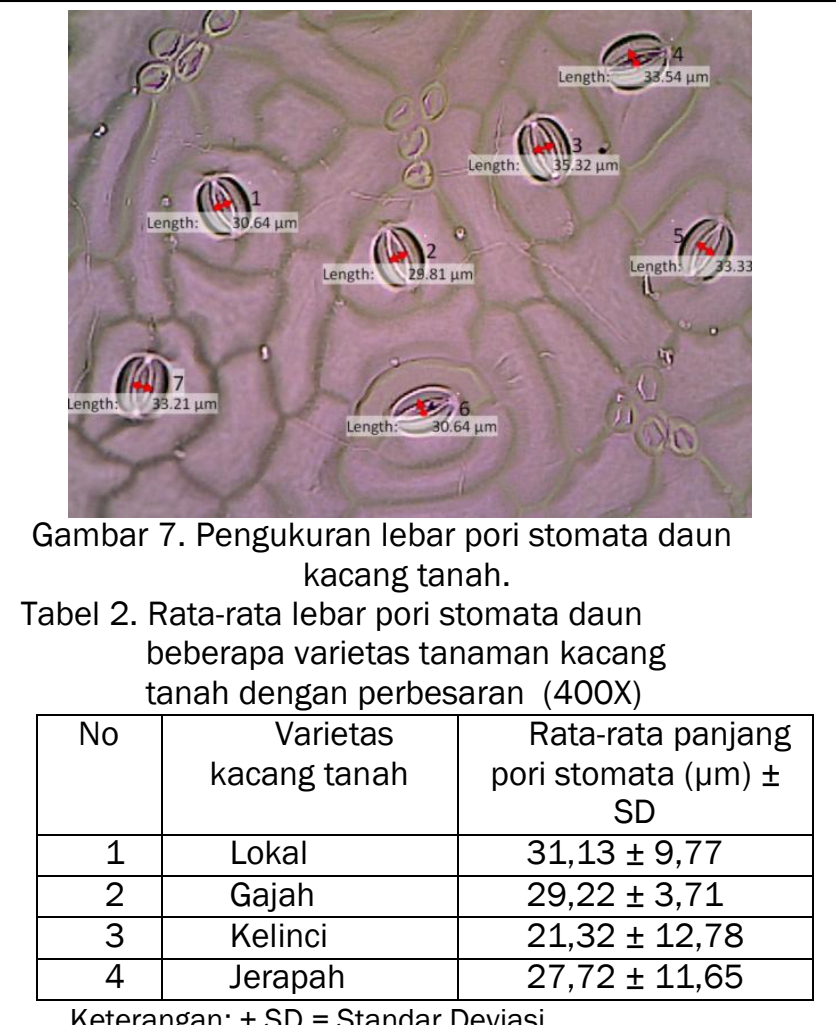

Keterangan: \pm SD = Standar Deviasi

Berdasarkan Tabel diatas bahwa data rata-rata lebar bukaan pori stomata tertinggi dari setiap varetas yaitu varietas lokal 31,13 $\pm 9,77 \mu \mathrm{m}$, diikuti dengan varietas gajah $29,22 \pm 3,71 \mu \mathrm{m}$, varietas jerapah $27,72 \pm 11,65 \mu \mathrm{m}$ dan varietas kelinci 21,32 $\pm 12,78 \mu \mathrm{m}$.

Bukaan pori stomata dengan lebar bukaan yang besar dapat menghasilkan produksi yang tinggi. Hal ini sesuai penelitian yang dilakukan oleh Yudiwanti (2006) yaitu bahwa stomata yang membuka lebar nyata berkorelasi dengan bobot polong isi dan bobot biji yang makin tinggi. Stomata merupakan pintu utama bagi masuknya $\mathrm{CO}_{2}$ ke dalam daun, yang pada gilirannya akan mempengaruhi kapasitas fotosintesis tanaman. Dalam proses difusi $\mathrm{CO}_{2} \mathrm{ke}$ dalam jaringan daun, stomata yang membuka lebih kecil difusi $\mathrm{CO}_{2}$ lebih rendah dibanding pada daun yang stomatanya membuka lebih besar.

Bukaan pori stomata dengan lebar bukaan yang besar dapat menghasilkan produksi yang tinggi. Hal ini sesuai penelitian yang dilakukan oleh Yudiwanti (2006) yaitu bahwa stomata yang membuka lebar nyata berkorelasi dengan bobot polong isi dan bobot biji yang makin tinggi. Stomata merupakan pintu utama bagi masuknya $\mathrm{CO}_{2}$ ke dalam daun, yang pada gilirannya akan mempengaruhi kapasitas fotosintesis tanaman. Dalam proses difusi $\mathrm{CO}_{2}$ ke dalam jaringan daun, stomata yang membuka lebih kecil difusi $\mathrm{CO}_{2}$ lebih rendah dibanding pada daun yang stomatanya membuka lebih besar.

Derajat pembukaan dan penutupan stomata penting pengaruhnya terhadap pengaturan aktivitas fotosintesis, terutama pada tanaman C3 yang secara langsung menggunakan $\mathrm{CO}_{2}$ melalui siklus Calvin. Halliwell (1984) juga mengemukakan bahwa penggunaan karbon dalam siklus Calvin dikendalikan oleh ketersediaan $\mathrm{CO}_{2}$, sedang ketersediaan $\mathrm{CO}_{2}$ tergantung tidak saja pada konsentrasinya di atmosfer, akan tetapi juga pada derajat pembukaan stomata daun (Devlin dan Witham, 1983).

Besarnya bukaan celah stomata menunjukkan bahwa terjadinya peningkatan laju transpirasi, sebagaimana yang telah dikemukakan oleh Gardner et al., 1985 dalam Elina et al., (2012) bahwa peningkatan laju transpirasi dapat dilakukan dengan memperbesar celah stomata atau jumlah stomata. Dengan transpirasi, penguapan air tetap berlangsung dan turgor yang berlebih dapat dicegah.Transpirasi dapat menurunkan potensial air di dalam sel sehingga turgor menjadi tidak terlalu tinggi, namun penutupan stomata penting untuk mencegah kehilangan air pada waktu persediaan air terbatas sekaligus membatasi pengambilan $\mathrm{CO}_{2}$ untuk fotosintesis.

Peningkatan laju transpirasi pada kacang tanah varietas kelinci lebih rendah dibandingkan dengan kacang tanah varietas lokal, gajah dan jerapah. Hal ini dapat dilihat dari kecilnya lebar pori yang dimiliki oleh varietas kelinci. Terjadinya perbedaan ini diduga karena ada perubahan tekanan turgor yang berbeda pada sel penutup ke-4 varietas tersebut.Lakitan (1996) mengatakan bahwa mekanisme menutup dan membukanya stomata tergantung dari tekanan turgor sel tanaman, atau karena perubahan konsentrasi karbondioksida, berkurangnya cahaya dan hormon asam absisat.Selanjutnya Fahn (1991) bahwa bertambah dan berkurangnya ukuran celah pada sel penutup adalah akibat perubahan tekanan turgor pada sel penutup.

Perubahan tekanan turgor ini disebabkan oleh masuknya air dari sel tetangga ke dalam sel penutup stomata, selanjutnya sel penutup mengalami kelebihan air (turgid) dan sel penutup mendorong dinding sel tetangga ke arah belakang menyebabkan stomata membuka. Stomata menutup apabila sel tetangga mengalami kelebihan air, sel penutup kekurangan air sehingga sel tetangga mendorong dinding sel penutup ke arah depan.

\section{Kesimpulan}

Berdasarkan hasil penelitian dan pembahasan, dapat disimpulkan bahwa panjang dan lebar pori stomata daun beberapa varietas kacang tanah adalah sebagai berikut:

1) Panjang pori stomata daun dari keempat varietas kacang tanah, yaitu varietas gajah dengan panjang $81,80 \pm 28,72 \mu \mathrm{m}$, varietas lokal 79,81 $\pm 24,85$ $\mu \mathrm{m}$, varietas jerapah $69,28 \pm 22,60 \mu \mathrm{m}$ dan varietas kelinci 57,22 $\pm 25,02 \mu \mathrm{m}$.

2) Lebar pori stomata daun dari keempat varietas kacang tanah, yaitu varietas lokal dengan lebar $31,13 \pm 9,77 \mu \mathrm{m}$, varietas gajah 29,22 $\pm 3,71 \mu \mathrm{m}$, varietas jerapah $27,72 \pm 11,65 \mu \mathrm{m}$ dan varietas kelinci 21,32 $\pm 12,78 \mu \mathrm{m}$. . 
Daftar Pustaka

Cambell, N.A, J.B. Reece and L.G.Mitchell. 2003. Biologi. (Terjemahan: L.Rahayu, E.I.M Adil, N Anita, Andri, W.F Wibowo, W.Manalu). Erlangga, Jakarta.

Dardjat, S dan A, Siregar. 1996. Fisiologi Tumbuhan. ITB, Bandung.

Devlin, R.M. and F.H. Witham. 1983. Plant Physiology. Willard Grant Press, Boston.

Elina, N; Fitmawati dan D. Iryani. 2012. Karakterisasi Anatomi Stomata DaunSagu (Metroxylon sagu Rottb.) Pada Tahap Anakan dan Nyorong. FMIPA Universitas Riau, Riau.

Fahn, A. 1991. Anatomi Tumbuhan (Terjemahan: Ahmad S. T. Koesoemaningrat). Gadjah Mada University Press, Yogyakarta.

Gardner F. P; R. B Pearce and R. L Mitchell. 1985. Physiology of Crop Plant. lowa: The lowa State University Press.

Halliwell, B. 1984. Chloroplast Metabolism: The Structure and Function of Chloroplastsin Green Leaf Cells. Clarendon Press, Oxford.

Haryanti, S dan M. Tetrinica. 2009. Optimalisasi Pembukaan Porus Stomata Daun Kedelai (Glycine max L. merril) Pada Pagi Hari dan Sore. BIOMA 11 (1): 11-16.

Kearn, E.V. and S. M. Assmann. 1993. The guard cells environ-mentconnection.Plant Physiology. 102: 711-715.

Lakitan, B. 2001. Dasar-dasar Fisiologi Tumbuhan. Raja Grafindo, Jakarta.

Lildahshiro. 2009. Fisiologi Tumbuhan. Kanisius, Jakarta.

Lovelles, A. R. 1991. Prinsip-Prinsip Biologi Tumbuhan Untuk Daerah Tropik. Gramedia Utama, Jakarta.

Meidner, $\mathrm{H}$ and Mansfield, T.A. 1968. Physiology of stomata. McGraw Hill, London.

Mulyani, S. 2006. Anatomi Tumbuhan. Kanisius, Yogyakarta.

Suhartina. 2005. Deskripsi varietas unggul kacangkacangan dan umbi-umbian. Balai Penelitian Tanaman Kacang-Kacangan dan Umbi-Umbian, Malang.

Sumargono, B. 1992. Pengaruh Kepadatan Lalu Lintas terhadap Jumlah dan Ukuran Stomata Daun Rambutan (Nephelium lappaceum). [Skripsi] F.MIPA UNDIP, Semarang.

Suprapto. 2000. Bertanam Kacang Tanah. Kanisius, Jakarta.

Yudiwanti. 2006. Pengaruh Antagonis Stomata Terhadap Ketahanan Pada Penyakit Bercak Daun Dan Daya Hasil Pada Kacang Tanah. [Prosiding] FAPERTA IPB, Bogor.

Wilkins, M. B. 1991. Fisiologi Tanaman I. Bina Aksara, Jakarta 